\title{
基于熵理论的山东省国家湿地公园管理绩效评价
}

\author{
赵志国 ${ }^{1}$, 杨 立 $^{2, *}$ ，王 青 $^{3}$ ，魏伯阳 ${ }^{1}$ \\ 1 国家林业和草原局调查规划设计院,北京 100714 \\ 2 中山大学生命科学学院, 广州 510275 \\ 3 亚太森林恢复与可持续管理组织, 北京 100102
}

摘要:量化评价管理绩效能为湿地公园管理措施的优化提供理论支持。选取山东省 68 个国家湿地公园作为研究对象, 从自然 环境、社会经济角度出发,选择植被覆盖率、废水排放量等 8 个指标构建指标体系。结合相关数据,基于熵理论定量评价国家级 湿地公园的管理绩效。结果表明, (1) 山东省整体总熵流为负 $(-0.3018)$, 其中 41 个湿地公园为负熵流, 系统趋于稳定, 管理绩 效提升; (2) 正熵流主要来自废水排放量 $(0.0854 \pm 0.0434)$, 负熵流则主要来自环保投人 $(-0.0802 \pm 0.0392)$; (3) 国民生产总值和 熵流呈现负相关关系，而第一产业产值比重和第二产业产值比重均和熵流呈现正相关关系。综合经济发展和熵流评价结果， 2 个市的湿地公园面临高管理风险,其中菏泽市需要引起注意; 山东省近海和海岸湿地的管理绩效较低,且面临高管理风险,应 当优先制定、开展保护治理规划。

关键词:管理绩效评价; 熵; 山东省; 国家湿地公园

\section{Quantitative assessment of management effectiveness of National Wetland Parks in Shandong Province based on entropy theory}

\author{
ZHAO Zhiguo $^{1}$, YANG Li ${ }^{2, *}$, WANG Qing ${ }^{3}$, WEI Boyang ${ }^{1}$ \\ 1 Academy of Forest Inventory and Planning, State Forestry and Grassland Administration, Beijing 100714, China \\ 2 School of Life Science, Sun Yat-sen University, Guangzhou 510275, China \\ 3 Asia-Pacific Network for Sustainable Forest Management and Rehabilitation, Beijing 100102, China
}

\begin{abstract}
Quantitative assessment of management effectiveness is important to provide reliable theoretical support for improving management measures of wetland parks. In this research, we developed an evaluation workflow composited by 8 indicators such as socio-economic and environmental sustainable, and applied entropy theory into quantitative assessment of management effectiveness of 68 National Wetland Parks in Shandong Province. The results showed that (1) Total entropy flow of 68 National Wetland Parks in Shandong Province was -0.3018 and 41 out of 68 were negative, indicating the system tended to be stable and management effectiveness are increased. (2) Positive entropy flow mainly contributed by Effluent volume, while negative values mainly came from expenditure for environment protection. (3) Gross national product and entropy flow were negatively correlated, while the proportion of the primary and secondary industry GDP were positively correlated respectively. Based on economic development situation and entropy flow analysis, we concluded that two cities' management of National Wetland Parks were under high risk in Shangdong Province, especially Heze city. And there exists low effective and high-risk management in coastal wetlands in Shangdong Province, which needs local government's foresight conservation planning.
\end{abstract}

基金项目:中国博士后科学基金(2019M653157); 国家自然科学基金青年基金(32000352); 中央高校基本科研业务费专项(19lgpy186)

收稿日期:2020-02-16; 网络出版日期:2021-07-05

*通讯作者 Corresponding author.E-mail: yangli53@ mail.sysu.edu.cn 
Key Words : assessment of management effectiveness; entropy; Shandong Province; National Wetland Park

湿地公园是湿地保护管理体系的重要组成部分, 既保护当地具有代表性的湿地生态系统, 又是开展科普 教育、生态旅游的重要平台 ${ }^{[1-2]}$,因此湿地公园对管理具有较高要求。科学有效的管理需要定期开展管理绩 效评价,进而适时修订管理策略,在确保湿地生态系统健康的前提下实现社会价值。

早期研究倾向于将湿地公园认为是保护地,进而设计相关指标,并依托长期监测数据,运用专家评分、层 次分析法等方法对湿地公园开展具体管理评价 ${ }^{[3-5]}$ 。湿地公园的具体管理评价是推动该湿地公园有效管理 的重要手段,而区域尺度的管理评价则为区域合作、区域环境治理及相关政策制定提供基础信息。随着我国 生态文明建设的推进, 全国重要生态系统保护也以区域为单位进行规划, 区域尺度的评价越发重要。但是, 区 域尺度的评价仍受制于数据缺乏,因为不同湿地公园的试点时间、湿地类型、监测系统等存在差异, 导致搜集 的数据内容、时间尺度等存在差异, 难以统一 ${ }^{[6-8]}$ 。随着 $3 \mathrm{~S}$ 技术推广, 已有学者利用卫星影像等数据, 将景观 尺度变化纳人指标体系, 量化人类活动对湿地景观的影响 ${ }^{[9]}$, 或者揭示湿地植被覆盖变化 ${ }^{[10]}$, 为宏观尺度上 湿地保护和管理提供支持。近年来, 相关学者逐渐重视在湿地公园相关评价中纳人管理因子, 比如旅游业、牧 业 $^{[8]}$ 、湿地管理能力 ${ }^{[11]}$ 、各管理部门投人 ${ }^{[12]}$ 等因子。因为湿地公园同时具有保护价值, 也具有重要的科普宣 教功能和经济价值, 所以我们不能单纯将湿地公园视为保护地 ${ }^{[12]}$, 应当综合考虑自然因素和社会因素, 构建 涉及保护和利用两个层面的指标体系,对湿地公园的管理绩效开展评价。

熵理论主要用于研究系统组成问题, 是量化系统无序程度的有效工具, 目前已经广泛应用于产业评

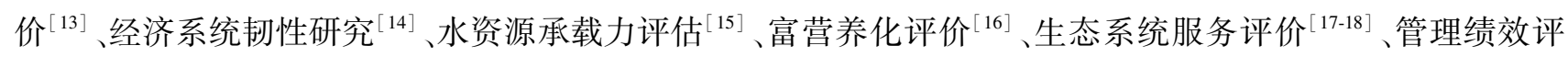
价 ${ }^{[19]}$ 等方面。本文将湿地生态系统看作具有层次结构的开放性复合体, 以具体的湿地公园视为子系统; 来自 环境因素和社会因素的有利因子和不利因子对系统的影响可以认为是负熵流和正熵流的输人,以总摘流的正 负来度量系统变化 ${ }^{[17,19-20]}$ 。如果总熵流为正, 则系统趋于无序, 管理绩效低; 反之, 则系统趋于有序, 管理绩 效较高。

山东省位于华北生境脆弱区, 是候鸟迁徙的重要区域,也是黄河流域及海岸带等重要生态系统保护和修 复的重要区域。截止 2017 年年底,国家林业和草原局共批准山东省国家级湿地公园 68 处,数量仅次于湖北 省 (70 处)。不仅如此,山东省既是经济大省 (2019 年 GDP 全国第三,山东省统计局网站, http://tjj.shandong. gov.cn/), 也是人口大省 (2019 年年末常住人口全国第二, 山东省统计局网站, http://tjj.shandong.gov.cn/), 湿 地公园保护与利用的矛盾突出。因此,本文选择山东省国家级湿地公园作为研究对象,将山东省所有国家湿 地公园作为子系统, 提取湿地生态系统管理绩效评价关键因子, 结合长时间尺度的空间生态数据和社会经济 指标,开展该区域的湿地公园管理绩效评价,为未来区域性湿地公园管理结构优化和政策引导提供理论支持。

\section{1 材料与方法}

\section{1 研究区域}

山东省地处中国黄河流域下游区域, 为温带季风气候; 气温 $12.9-16.0^{\circ} \mathrm{C}$, 年降雨 $596-1112 \mathrm{~mm}$ ( 山东省 统计局,山东统计年鉴 2019, http://tjj.shandong.gov.cn/)。本次研究包括山东省全部国家级湿地公园 (图 1), 共计 68 处,涉及山东省全部 17 个市。所有湿地公园中 61 个湿地公园范围信息完整,剩余 7 个仅有中心点。 按湿地类型分河流湿地 32 处、湖泊湿地 6 处、人工湿地 21 处、沼泽湿地 2 处、近海与海岸湿地 7 处。

\section{2 构建评价指标体系}

综合考虑指标代表性、数据可获得性 ${ }^{[4,14,17-19,21]}$, 本文选择八个因子构建指标体系,开展山东省国家级湿 地公园生态管理绩效评价 (表 1)。首先, 本文认为湿地是一个开放系统, 受到自然因素、宏观管理投人的影 响。有利因子中, 年降雨量会直接影响河流湿地、库塘湿地的水量, 影响湿地生态系统的碳收支等一系列生态

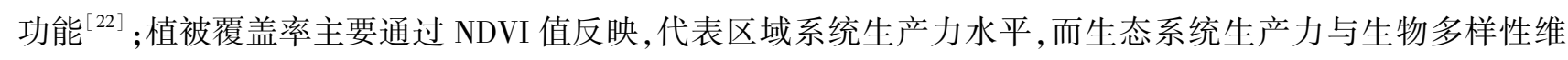




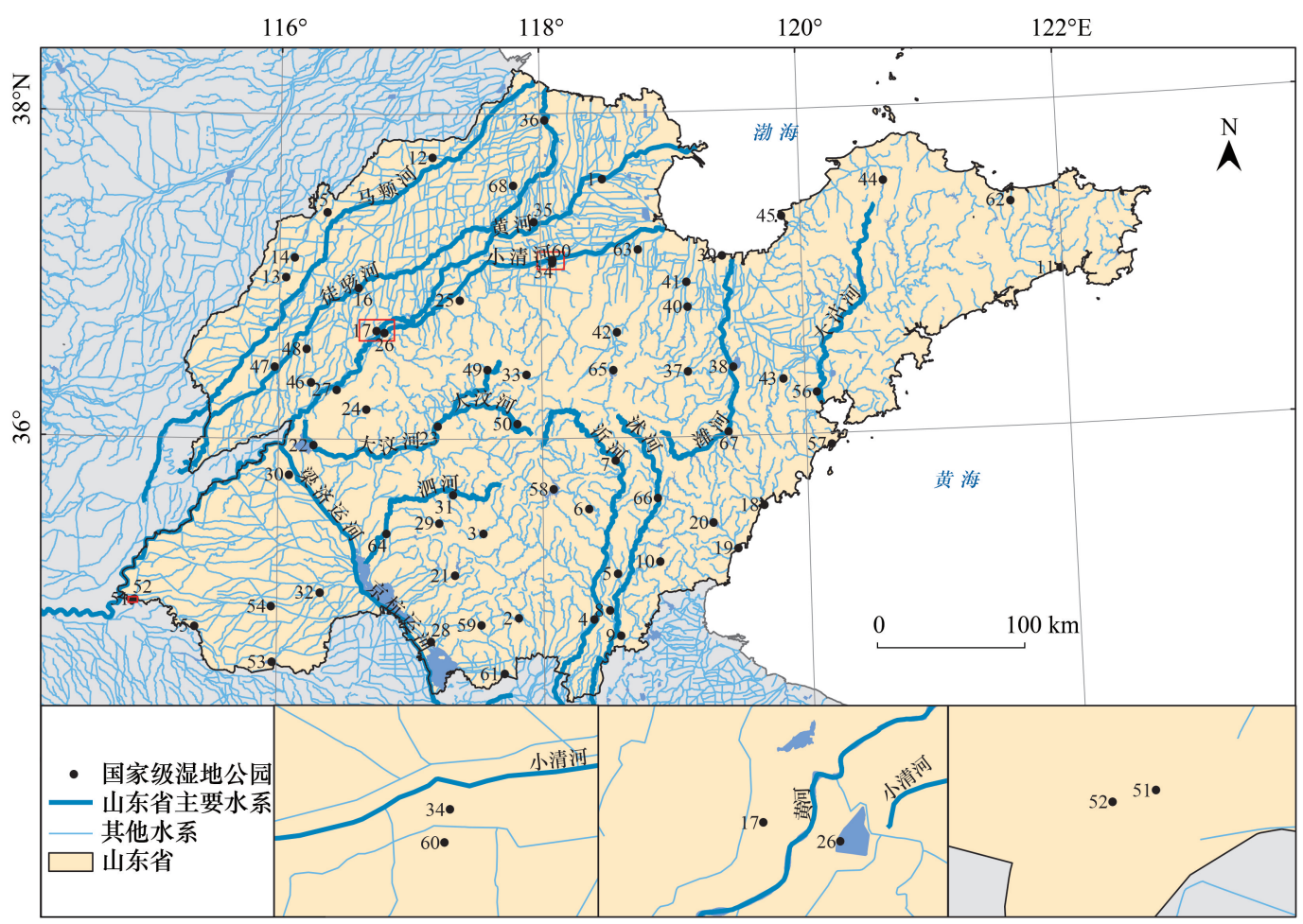

图 1 山东省国家级湿地位置示意图

Fig.1 Location of national wetland parks in Shandong Province

1 旺利天宁湖国家湿地公园; 2 兰陵会宝湖国家湿地公园; 3 平邑浚河国家湿地公园 ; 4 武河国家湿地公园 ; 5 汤河国家湿地公园; 6 沂南汶 河国家湿地公园； 7 沂水国家湿地公园；8 沂沭河国家湿地公园；9 莒南鸡龙河国家湿地公园；10 威海五垒岛湾国家湿地公园；11 乐陵跃 马河国家湿地公园；12 夏津九龙口国家湿地公园；13 德州减河国家湿地公园；14 禹城徒骇河国家湿地公园；15 齐河黄河水乡国家湿地公 园；16 日照两城河口国家湿地公园；17 日照傅疃河口国家湿地公园；18 日照西湖国家湿地公园；19 月亮湾国家湿地公园；20 东平滨湖国 家湿地公园；21 泰安汶河国家湿地公园；22 肥城康王河国家湿地公园；23 济南白云湖国家湿地公园；24 济西国家湿地公园；25 黄河玫瑰 湖国家湿地公园 ; 26 微山湖国家湿地公园; 27 曲阜孔子湖国家湿地公园; 28 梁山泊国家湿地公园; 29 泗水泗河源国家湿地公园;30 金乡 金水湖国家湿地公园；31 博山五阳湖国家湿地公园；32 博兴麻大湖国家湿地公园；33 滨州秦皇河国家湿地公园；34 黄河岛国家湿地公 园; 35 安丘拥翠湖国家湿地公园 ; 36 峡山湖国家湿地公园；37 昌邑滨海国家湿地公园；38 潍坊白浪河国家湿地公园；39 滩坊禹王国家湿 地公园； 40 青州弥河国家湿地公园； 41 高密胶河国家湿地公园； 42 王屋湖国家湿地公园； 43 莱州湾金仓国家湿地公园； 44 东阿洛神湖国 家湿地公园; 45 聊城东昌湖国家湿地公园；46 茌平金牛湖国家湿地公园； 47 莱芜雪野湖国家湿地公园；48 钢城大汶河国家湿地公园； 49 东明黄河国家湿地公园；50 单县浮龙湖国家湿地公园；51 成武东鱼河国家湿地公园；52 曹县黄河故道国家湿地公园; 53 少海国家湿地公

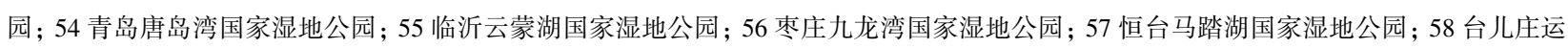
河国家湿地公园；59 牟平沁水河口国家湿地公园； 60 寿光滨海国家湿地公园 61 邹城太平国家湿地公园； 62 沂沭河国家湿地公园；63 莒 县沭河国家湿地公园； 64 诸城滩河国家湿地公园； 65 滨州小开河国家湿地公园；66 滕州滨湖国家湿地公园；67 菄庄蟠龙河国家湿地公 园; 68 临朐弥河国家湿地公园; 主要数据来自湿地中国 (http://www. shidi. org/) 和全国地理信息资源目录服务系统 (http://www. webmap.cn/)

持、生态服务功能体现相关 ${ }^{[10,23]}$;湿地面积所占比例是湿地公园所在市县的湿地面积占市县面积的比例,该 比例在一定程度上反映该公园所处的湿地生态系统在当地生态系统的比重; 节能环保支出主要涉及节能减 排、水域治理、污染防治等具体科目,该投人能够从水质维持、植被保护、污染治理等方面降低湿地公园的生态 管理压力。在不利因子中, 最热月均温是气候变化的度量指标, 高温通过影响植被演替过程和碳交换过程等 生态过程, 最终影响湿地的生态功能 ${ }^{[24]}$; 蒸发量不利于湿地保持水量; 农田面积所占比例, 农业活动涉及化肥 和农药污染, 面积越大, 潜在影响越大, 对湿地公园的保护压力越大 ${ }^{[10-11]}$;工业废水和生活污水的排放将直接 影响水质, 不利于湿地保护。其中, 本文认为节能环保投人、农田影响和污水排放三个指标具备区域影响力, 
故选取该湿地公园所在城市的数据(年鉴数据、地表覆盖数据)开展分析。

表 1 湿地公园管理绩效量化评价指标体系

Table 1 The indicators for quantitative evaluation of effectiveness management of wetland parks

\begin{tabular}{|c|c|c|}
\hline $\begin{array}{l}\text { 影响因子 } \\
\text { Variable }\end{array}$ & $\begin{array}{l}\text { 数据来源 } \\
\text { Data resource }\end{array}$ & $\begin{array}{l}\text { 熵流数值 (均值 } \pm \text { 方差 (最小值-最大值) }) \\
\text { Entropy flow value: Mean } \pm \text { sd ( } \min -\max )\end{array}$ \\
\hline $\begin{array}{l}\text { 年降雨量 }(-) \\
\text { Annual precipitation }\end{array}$ & Climate $\mathrm{AP}^{[30]}$ & $-0.0767 \pm 0.0424(-0.3772--0.0087)$ \\
\hline $\begin{array}{l}\text { 植被覆盖率 }(-) \\
\text { Vegetation coverage }\end{array}$ & MCD12Q1 v006 ${ }^{[26]}$ & $-0.0791 \pm 0.0491(-0.3853--0.0078)$ \\
\hline $\begin{array}{l}\text { 湿地面积所占比例 }(-) \\
\text { The proportion of wetland area }\end{array}$ & MCD12Q1 v006 ${ }^{[26]}$ & $-0.0722 \pm 0.0519(-0.3853--0.0078)$ \\
\hline $\begin{array}{l}\text { 节能环保支出 }(-) \\
\text { Expenditure for environment protection }\end{array}$ & 年鉴数据 & $-0.0802 \pm 0.0392(-0.2743--0.0102)$ \\
\hline $\begin{array}{l}\text { 最热月均温 }(+) \\
\text { Mean temperature of the warmest month }\end{array}$ & Climate $\mathrm{AP}^{[30]}$ & $0.0734 \pm 0.0389(0.3335-0.0080)$ \\
\hline $\begin{array}{l}\text { 蒸发量 }(+) \\
\text { Hargreaves reference evaporation }\end{array}$ & Climate $\mathrm{AP}^{[30]}$ & $0.0713 \pm 0.0343(0.2775-0.0084)$ \\
\hline $\begin{array}{l}\text { 农田面积所占比例 }(+) \\
\text { The proportion of farmland }\end{array}$ & MCD12Q1 v006 ${ }^{[26]}$ & $0.0735 \pm 0.0519(0.3853-0.0078)$ \\
\hline $\begin{array}{l}\text { 废水排放量 }(+) \\
\text { Effluent volume }\end{array}$ & 年鉴数据 & $0.0854 \pm 0.0434(0.3733-0.0079)$ \\
\hline
\end{tabular}

-表示负熵流, 为有利因子;+表示正熵流, 不利因子

\section{3 数据获取}

湿地公园的管理应当关注公园区划范围和周边环境。因此本文以湿地公园范围或中心点生成 $10 \mathrm{~km}$ 缓 冲区, 并以湿地公园及其缓冲区作为样本研究范围, 对环境数据进行提取。对于气候数据( 年降雨量、最热月 均温和蒸发量), 本文在区域内部生成 50 个随机点, 在 ClimateAP 中提取气候数据 ${ }^{[25]}$, 最终计算各年度各个 湿地公园气候数据的平均值。

对于其他环境数据, 本文均以市为单位进行提取或者获取,各市的范围来自全国地理信息资源目录服务 系统 (http://www.webmap.cn/)。其中,地类数据来自 Earthdata Search (https://search.earthdata.nasa.gov/, 数 据产品为 MCD12Q1 v006, 空间分辨率为 $500 \mathrm{~m})^{[26]}$ 。本文利用 $\mathrm{R}$ (raster 包) 对数据进行提取,计算各个湿地 所在市的植被覆盖率、湿地面积所占比例和农田面积所占比例。节能环保支出和废水排放量则来自年鉴数 据。年鉴数据主要来自山东省统计局网站 ( http://tjj. shandong.gov.cn/) 及各市统计局网站,部分来自中国知 网年鉴数据库 (https://www.cnki.net/)。所有数据的时间尺度均为 2008-2017 年。

\section{4 数据缺失}

其中日照市、德州市和聊城市的年鉴数据存在部分缺失。本文利用 $\mathrm{R}$ 软件 mice 包, 依托 MICE (Multivariate Imputation by Chained Equations) 的方法, 对缺失数据进行插补 ${ }^{[27]}$ 。

\section{5 数据分析}

\subsection{1 计算年际间熵流、总熵流的变化}

参考前期研究的计算方法 ${ }^{[17,19]}$, 本文计算单个湿地公园 2008-2017 年的年际间熵流、总熵流。结合各 个湿地公园试点时间,计算试点前后湿地公园总熵流。同时计算山东省的年际间熵流、总熵流。

\subsection{2 熵流与经济的关系}

本文搜集湿地公园所在市域的国内生产总值(GDP)、第一产业比重、第二产业比重、第三产业比重和人 均 GDP。利用方差膨胀系数 (VIF) 去除部分因子,防止过度拟合影响, 该统计在 R 环境下利用 usdm 包进行计 算 ${ }^{[28]}$ 。最终,仅选择国内生产总值、第一产业比重、第二产业比重用于计算。

本文将各个湿地公园十年来的年际间熵流作为因变量, 三个经济特征作为自变量,湿地类型和城市作为 随机变量,运用广义线性混合模型了解熵流与经济发展之间的关系。在 R 环境下利用 lme4 和 MuMin 包进行 
计算,基于 AICc (Corrected Akaike information criterion)对模型结果进行篮选;仅选择 delta $<2$ 的模型进行模型 平均,得到最终结果 ${ }^{[29]}$ 。湿地公园的管理受所在城市宏观管理政策影响,而同一类型的湿地公园则通常遵循 类似的管理手段,因此本文将 68 个湿地公园的总熵流为基础,计算不同城市或湿地类型的总熵流。本文将总 熵流结合经济因子,综合评价不同城市或不同湿地类型的管理绩效,并将评价结果可视化。

\section{2 结果}

2.1 指标熵流的变化

各个湿地公园熵流计算结果表明,正熵流指标中废水排放量总熵流最大,其次为农田面积占比。最近十 年间山东省废水排放量逐年增加, 平均增幅为 $(22.98 \pm 22.81) \%$; 农田面积占比逐年减少, 平均下降幅度为 $(5.35 \pm 6.19 \%$ 。负熵流则主要来自环保投人, 其次为植被覆盖率。最近十年间山东省环保投人力度不断加 大, 增幅 $(71.95 \pm 12.51) \%$; 植被覆盖率则呈现增长趋势, 平均增幅 $(31.90 \pm 38.99) \%$ 。从不同湿地类型上看, 河 流湿地、人工湿地的负熵流主要来自植被覆盖率;湖泊湿地、沼泽湿地的负熵流主要来自年均降雨量; 河流湿 地 \& 人工湿地、近海和海岸湿地的负熵流主要来自环保投人。所有湿地类型正熵流主要来自废水排放量。

2.2 不同湿地公园熵流变化

山东省 10 年整体总熵流为 -0.3018 ; 其中, 2009 年总熵流最高为 $5.9785,2015$ 年总熵流最小为 -6.4955 。 有 41 个湿地公园为负熵流 (平均值 \pm 标准差: $-0.2901 \pm 0.22$ ), 27 个为正熵流 $(0.3209 \pm 0.18$ ) (图 2)。随着时 间推移,负熵流的湿地公园数量逐渐增多(图 3)。

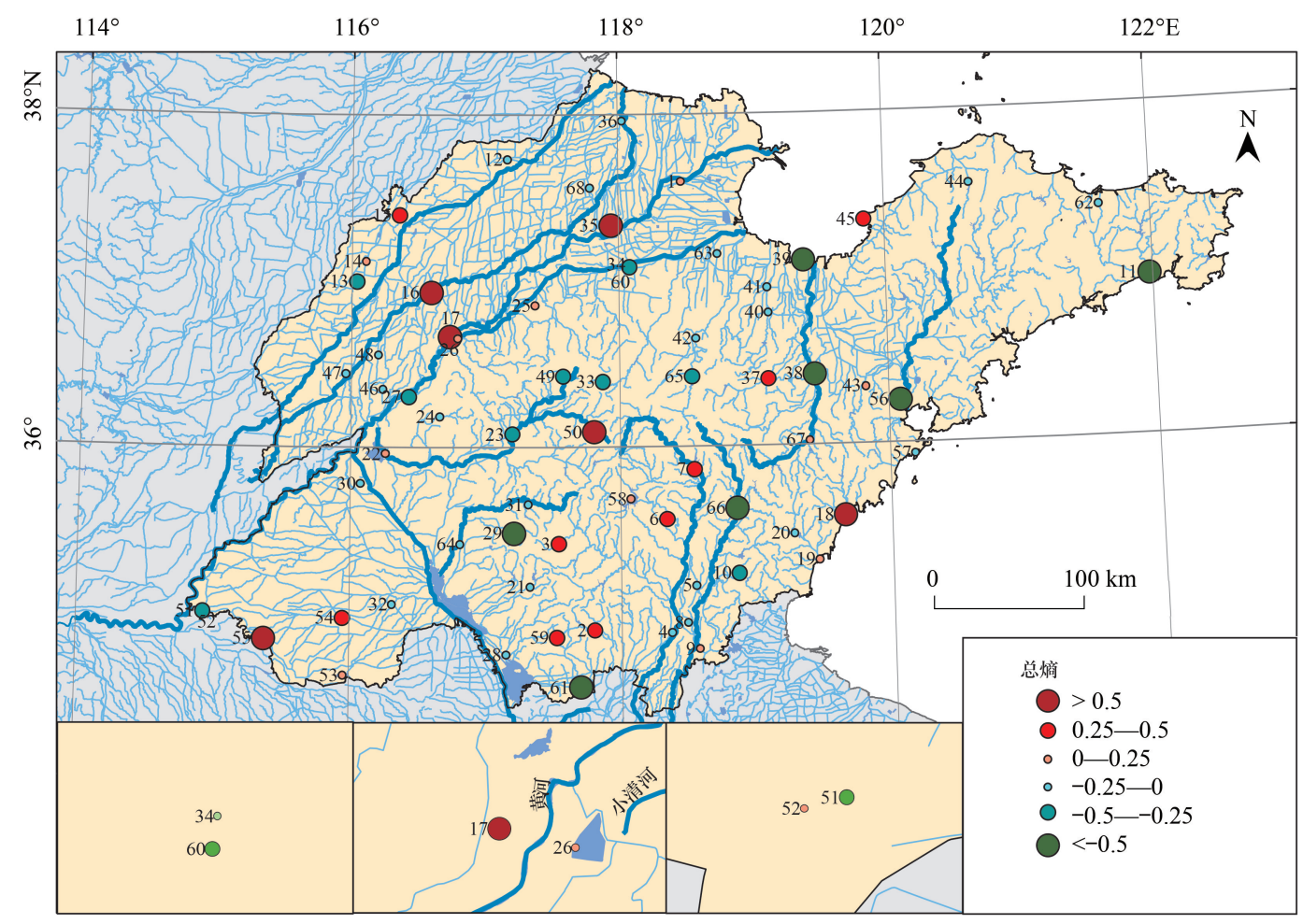

图 2 山东省各个国家级湿地公园过去 10 年总摘流

Fig.2 Total entropy flow for past ten years to each national wetland park in Shandong Province

\section{3 湿地公园生态管理与经济发展的关系}

模型平均结果显示, $\mathrm{GDP}($ 估算值 $=-0.2748, \mathrm{SE}=0.049, P<0.01)$ 与总熵流负相关, 而第一产业 GDP 比 重 $($ 估算值 $=-0.7107, \mathrm{SE}=0.214, P<0.01)$ 和第二产业 GDP 比重 $($ 估算值 $=-0.270, \mathrm{SE}=0.103, P=0.0292<$ $0.05)$ 与总熵流正相关。 

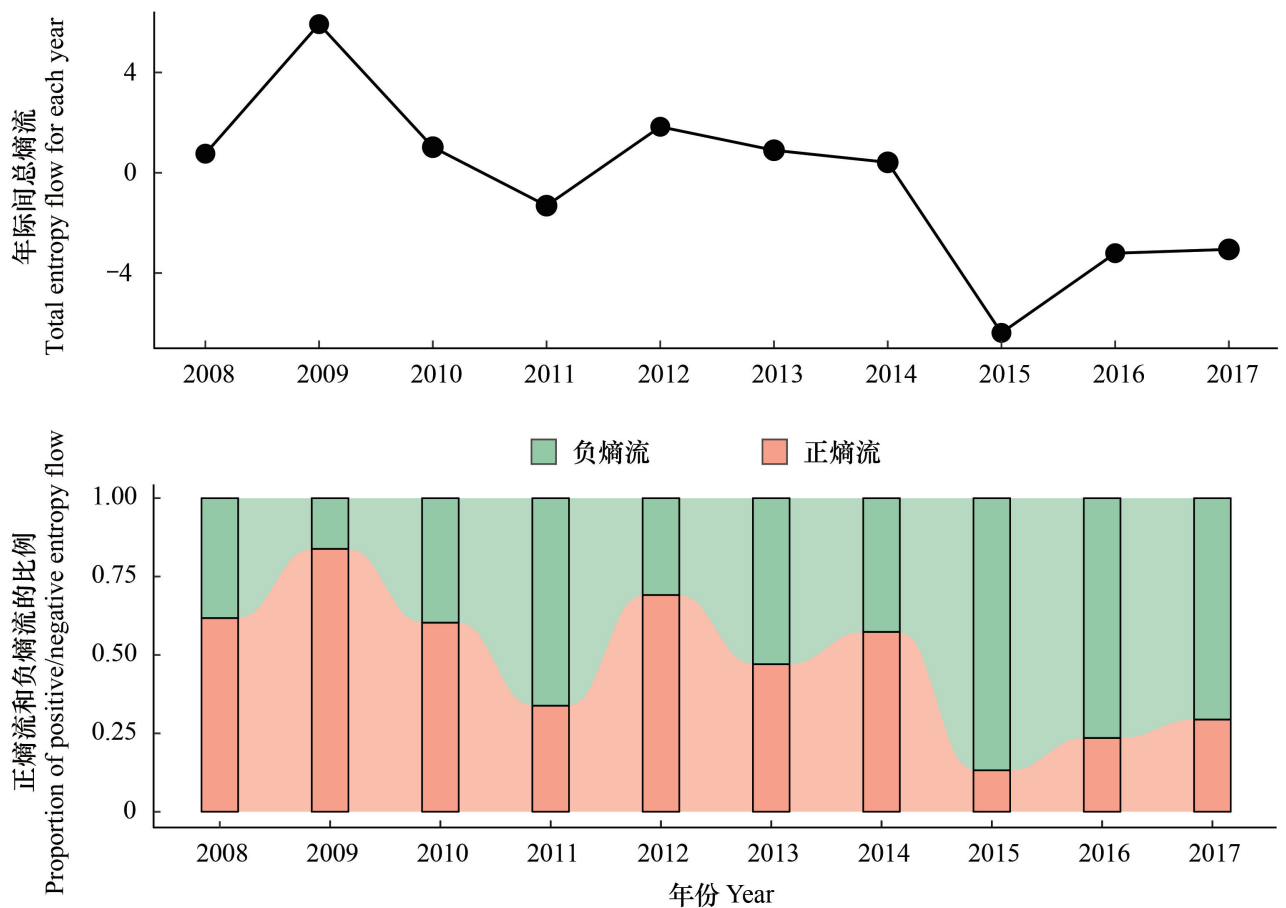

图 3 山东省年际间熵流变化

Fig.3 Entropy flow for each year in Shandong Province

某个城市或者某种类型的湿地公园所处区域具有较高的 GDP (高于均值)、较低的第一产业(低于均值) 和第二产业比重(低于均值), 则管理风险较低(图 4 绿色三角区域); 反之, 则具有较高的管理风险 (图 4 红色 三角区域)。图 4 显示,在涉及 17 个市中, 7 个为正熵流,其中临沂市和泰安市为高管理风险地区 (正熵流主 要来自废水排放), 应当予以重视。在负熵流的城市中, 淄博市面临较高管理风险, 而济南市风险低, 可以作 为管理绩效示范区域。沼泽湿地、近海和海岸湿地为正熵流 (主要来自废水排放), 其中近海和海岸湿地存在 较高管理风险。剩余四种类型均为负熵流,其中湖泊湿地具有较低的管理风险。

\section{3 讨论}

本文采用熵理论对山东省国家级湿地公园的管理绩效开展定量评价。相比前人研究,本研究注重 (1) 对 湿地公园开展时空尺度上的管理绩效评价; (2) 构建管理绩效与宏观经济因素的关系。不仅如此,本研究采 用地方统计年鉴和开源数据库,结合湿地公园矢量数据进行提取、篮选、校对,数据可获得性强,可以作为规 划、区域管理方案等政策制定的参考。

\section{1 基于熵理论的评价体系}

运用熵流评价管理绩效需要关注两方面问题, (1) 由于本文用熵的正负来衡量系统状态, 需要对选择的 因子进行正熵和负熵的定义,不能存在中性因子。本文无法忽视某个指标对管理绩效同时存在正面和负面影 响, 仅能根据前人研究结果定义因子。本研究涵盖山东省所有国家级湿地公园,搜集数据涉及自然生态系统 和社会因素,且时间尺度长达十年,管理绩效评价结果具备代表性。后续研究可以关注指标选择以及不同指 标选择结果可能带来的潜在的管理评价偏差。(2) 熵流仅能评价在某一特定时空范围内的复合系统的整体 变化和各个子系统的相对变化。因此,本研究结果中总熵流为正的湿地公园、城市或者湿地类型并非直接代 表管理绩效下降,而是和山东省其他湿地公园、城市或者湿地类型相比,管理绩效相对较低。

\section{2 影响管理绩效的经济因子}

模型模拟结果表明,GDP 是积极因子 (与总熵流负相关:GDP 增长, 总熵流下降), 而第一产业和第二产业 

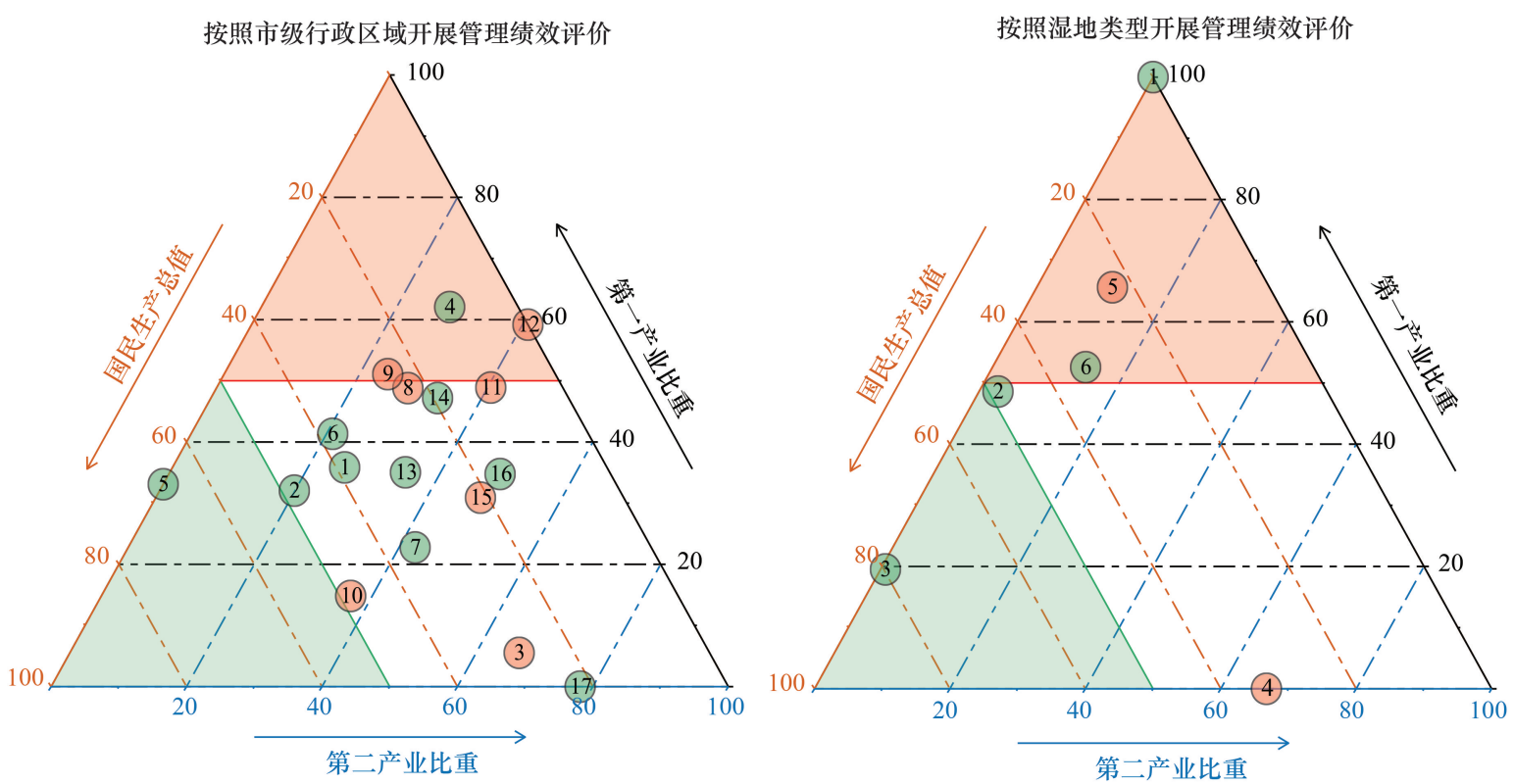

图 4 山东省国家湿地公园管理绩效评价

Fig.4 Assessment of managemental effectiveness of national wetland parks in Shandong Province

市级行政区域评价:1.滨州市；2.德州市；3.东营市；4.菏泽市；5.济南市；6.济宁市；7.莱芜市；8.聊城市；9.临沂市；10.青岛市；11. 日照

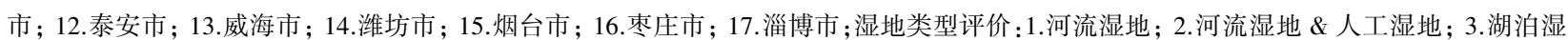
地; 4. 沼泽湿地; 5 .近海和海岸湿地; 6. 人工湿地; 红色圆圈为正熵流, 绿色圆圈为负熵流;红色三角区域为高管理风险, 绿色区域为低管理 风险

比重为消极因子。随着生态文明建设推进和产业结构升级,GDP 增长带来的经济增长,更多依靠第三产业带 动 ${ }^{[31]}$; 第三产业占比提升,有伴随着第一产业、第二产业比重下降,进而降低环境压力 ${ }^{[3,10]}$ 。随着生态管理理 念的推广, 经济增长也带动环保投入增加, 最终提升区域湿地公园管理绩效 ${ }^{[31]}$ 。

\section{3 管理建议}

(1) 湿地公园的管理绩效评价需要考虑自然因素和社会因素,需要整合多数据来源,因此各个管理部门 之间数据共享尤为重要。应当针对省内湿地公园的监测方案进行梳理,在本研究基础上提取并优化用于宏观 尺度评价的指标。在此基础上,湿地公园管理部门应当建立数据共享机制,或者构建数据共享平台,推动相关 管理指标的数据在湿地管理的应用。比如,利用数据共享平台提升河长制的区域化管理能力,包括识别管理 空缺区域和优先监测区域、定期对流域开展管理绩效评价等。

(2)正熵流指标主要来自废水排放量,而负熵流则主要来自环保投人。水污染仍是湿地公园管理面临的 最重要挑战 ${ }^{[32]}$, 因此在 “十四五” 规划中, 山东各级城市仍然需要确保环保投人的持续稳定, 同时环保投人需 要侧重水污染治理。

(3) 总熵流为正的 7 个城市需要密切关注当地社会经济发展对湿地公园管理的影响,尤其是东营市,需 要重点关注污水治理; 菏泽市虽然总摘流为负, 但是所处环境具有高管理风险, 同样需要警惕经济发展带来的 影响。近海和海岸湿地的管理同样需要引起重视, 应当优先制定、开展全面保护治理规划 (涉及污水治理和 加大环保投人)。不仅如此,黄河下游有两个国家级湿地公园具有较高正熵流 (正熵流主要来自废水排放), 不利于黄河流域生态保护和高质量发展,需要及时开展调研,尽快开展全面保护治理。

\section{4 结论}

本文综合空间数据和年鉴数据, 基于熵理论定量评价山东省国家湿地公园管理绩效。结果显示, (1) 过 
去十年,山东省国家湿地公园的管理绩效提升 (总熵为负);(2) 废水排放量是重要的不利因子,环保投人则是 重要的有利因子; (3) 国民生产总值提升有利于提升管理绩效,而与第一产业产值比重和第二产业产值比重 的提升则不利于管理绩效提升; (4)综合经济发展和熵流评价结果, 临沂市和泰安市 (总熵流为正,需要重点 关注) 和菏泽市的湿地公园面临高管理风险; 山东省近海和海岸湿地的管理绩效较低, 且面临高管理风险, 应 当优先制定、开展全面保护治理规划。此外,本文的评价方法数据获得性强,适合开展较大空间尺度和较长时 间尺度的评价，可以作为规划、区域管理方案等政策制定的参考。

致谢: 杨奋斌、赣南师范大学黄艳芳协助年鉴数据搜集和整理, 中山大学生命科学学院汪巧云博士、马长勇博 土帮助写作,特此致谢。

\section{参考文献 (References) :}

［1］雷昆. 对我国湿地公园建设发展的思考. 林业资源管理, 2005, (2) : 23-26.

[2] 刘国强. 我国湿地公园规划、建设与管理问题的思考. 湿地科学与管理, 2006, 2(3): 21-24.

[ 3 ] 朱金峰, 周艺, 王世新, 王丽涛, 刘文亮, 李海涛, 梅军军. 白洋淀湿地生态功能评价及分区. 生态学报, 2020, 40(2) : 459-472.

[ 4 ] 赵志江, 崔丽娟, 朱利, 李伟. 指标体系法在我国湿地生态系统健康评价研究中的应用进展. 湿地科学与管理, 2018, 14(4): 9-13.

[ 5 ] Stoll-Kleemann S. Evaluation of management effectiveness in protected areas: methodologies and results. Basic and Applied Ecology, 2010, 11 (5) : 377-382.

［6］周记超,张开峰，马波涛，塞卫卫. 书院洲国家湿地公园湿地科研监测技术研究. 绿色科技, 2019, (8): 35-38.

[ 7 ] 马晓伟. 湖南省湿地分类系统及监测指标体系研究. 长沙: 中南林业科技大学, 2009.

[ 8 ] 吴瑶, 孙治宇. 国家湿地公园生态监测指标体系及案例分析. 四川林业科技, 2016, 37(4) : 69-73.

[9]陈柯欣, 丛不福, 雷威. 人类活动对 40 年间黄河三角洲湿地景观类型变化的影响. 海洋环境科学, 2019, 38(5): 736-744, 750-750.

[10］杨楠, 莫文波, 张曦, 罗望军, 张灿明, 赵运林, 马丰丰. 近 30 年来东洞庭湖植被覆盖时空变化研究. 中南林业科技大学学报, 2019,39 (7) : 19-30.

[11] 朱锦, 朱卫红, 金日, 张达, 于瑶. 中国图们江流域湿地生态系统健康评价研究. 湿地科学, 2019, 17(3): 344-351.

[12］张蹟, 贺桂珍, 吕永龙. 基于 AHP-DEA 的滨海湿地保护利用管理效率评价. 生态学报, 2020, 40(15) : 5210-5219.

[13] 陈盛伟, 冯叶. 基于熵值法和 TOPSIS 法的农村三产融合发展综合评价研究一一山山东省为例. 东岳论丛, 2020, 41(5): 78-86.

[14] 孙才志, 曹强, 邹玮. 基于熵效率模型的环渤海地区海洋经济系统韧性研究. 宁波大学学报: 理工版, 2020, 33(1): 10-18.

[15］金菊良, 刘金金, 周戎星, 崔毅, 张浩宇, 陈鹏飞. 联系熵方法在水资源承载力评价中的应用. 西北大学学报: 自然科学版, 2020, 50(3)： 447-455.

[16] 宋景辉, 刘汉湖, 付博, 程涵宇, 张双圣. 基于熵权法的富营养化二级模糊综合评价模型: 以江苏九里湖国家湿地公园为例. 环境工程, 2020, 38(9): 126-132.

[17] 李婧昕, 杨立, 杨蕾, 张超, 霍兆敏, 陈敏豪, 奕晓峰. 基于熵理论的城市生态系统服务流定量评估一一北京市为例. 应用生态学报, 2018, 29(3): 987-996.

[18］间志刚, 李俊清. 基于熵值法与变异系数的大熊猫分布区生态系统评价. 应用生态学报, 2017, 28(12)：4007-4016.

[19] 赵志国, 橸晓峰, 陈君帜, 叶菁, 李婧昕, 张超, 李苗苗, 王贺崐元, 杨立. 基于信息熵量化评价大熊猫国家公园生态系统管理成效. 生 态学报, 2019, 39(11): 3885-3894.

[20］刘涛. 基于耗散结构的农村生态环境保护动态熵模型研究. 生态经济, 2012, (12)：185-188.

[21] 孙平军, 修春亮, 张天娇. 滳变视角的吉林省城市化与生态环境的耦合关系判别. 应用生态学报, 2014, 25(3): 875-882.

[22] 初小静, 韩广轩. 气温和降雨量对中国湿地生态系统 $\mathrm{CO}_{2}$ 交换的影响. 应用生态学报, 2015, 26(10) : 2978- 2990 .

[23] 张德君, 高航, 杨俊, 席建超, 李雪铭. 基于 GIS 的南四湖湿地生态脆弱性评价. 资源科学, 2014, 36(4) : 874-882.

[24] Lefebvre G, Redmond L, Germain C, Palazzi E, Terzago S, Willm L, Poulin B. Predicting the vulnerability of seasonally-flooded wetlands to climate change across the Mediterranean Basin. Science of the Total Environment, 2019, 692: 546-555.

[25] Wang T L, Wang G Y, Innes J L, Seely B, Chen B Z. ClimateAP : an application for dynamic local downscaling of historical and future climate data in Asia Pacific. Frontiers of Agricultural Science and Engineering, 2017, 4(4) : 448-458.

[26] Friedl M, Sulla-Menashe D. MODIS/Terra + Aqua Land Cover Type Yearly L3 Global 500m SIN Grid V006//NASA LP DAAC. USA: Boston University and MODAPS SIPS, 2015. (https://lpdaac.usgs.gov/products/mcd12q2v006/)

[27] van Buuren S, Groothuis-Oudshoorn K. MICE : multivariate imputation by chained equations in R. Journal of Statistical Software, 2011, 45(3) : 1-67.

[28] Dormann C F, Elith J, Bacher S, Buchmann C, Carl G, Carré G, Marquéz J R G, Gruber B, Lafourcade B, Leitão P J, Münkemüller T, McClean C, Osborne P E, Reineking B, Schröder B, Skidmore A K, Zurell D, Lautenbach S. Collinearity : a review of methods to deal with it and a simulation study evaluating their performance. Ecography, 2013, 36(1): 27-46.

[29] Burnham K P, Anderson D R. Model Selection and Multimodel Inference: A Practical Information-Theoretic Approach. New York: Springer, 2002.

[30] Wang T L, Hamann A, Spittlehouse D L, Murdock T Q. ClimateWNA-high-resolution spatial climate data for Western North America. Journal of Applied Meteorology and Climatology, 2012, 51(1): 16-29.

[31] 郭子良, 张曼胤, 崔丽娟, 杨思, 王贺年, 魏圆云, 李梦洁. 中国国家城市湿地公园的建设现状及其趋势分析. 湿地科学与管理, 2018, 14(1): 42-46.

[32] 赵广东, 王兵, 靳芳. 中国湿地生态环境质量及湿地自然保护区管理. 世界林业研究, 2004, 17(6) : 35-39. 